\title{
AMBIENTE VIRTUAL DE APRENDIZAGEM: UMA ESTRATÉGIA PARA O ENSINO DOS SUPORTES BÁSICOS E AVANÇADOS DE VIDA
}

\author{
Jacon JC'1; Parro $\mathrm{MC}^{2}$; Beccaria $\mathrm{LM}^{3}$
}

INTRODUÇÃO: A aprendizagem por meio das tecnologias da informação e comunicação (TICs) ocorre por meio de Ambiente Virtual de Aprendizagem (AVA) ou Virtual Learning Environments (VLE), definidos por sistemas computacionais no espaço virtual com finalidade de promover atividades educacionais que enfatizam a comunicação entre alunos e docentes, e possibilitam maior exercício de autonomia e desenvolvimento de novas habilidades. Nessa modalidade de ensino, a construção do saber é apoiada por uma interação de mídias e, sobretudo, por uma liberdade de tempo e espaço no que se refere ao processo de aprendizado ${ }^{1,2}$. Acredita-se que as estratégias de educação online tenham grande potencial na geração de conhecimento, inclusive na área de saúde ${ }^{1}$. Pois um AVA utiliza métodos por meio dos quais otimiza a dinâmica da sala de aula, proporciona um melhor aproveitamento dos conteúdos teóricos, torna-os mais atrativos, e personaliza a aprendizagem à medida que permite ao aluno a possibilidade de acessar 0 ambiente em local e tempo a critério de sua disponibilidade e o torna responsável por seu próprio estudo ${ }^{3}$.Considerando tais avanços tecnológicos na área de educação em saúde, idealizou-se renovar os tradicionais métodos e materiais utilizados para o ensino ao atendimento à parada cardiorrespiratória (PCR) com a exploração de inovadores recursos computacionais e midiáticos. Visando elevar a eficiência dos treinamentos dos socorristas uma vez que se trata de um evento importante, quando estimativas nacionais demonstram que aproximadamente 200.000 PCRs ocorrem por ano no Brasil, sendo metade dos casos em ambiente hospitalar, e a outra metade em ambiente extrahospitalar. E ainda que, a presença de um socorrista treinado é o principal determinante da sobrevivência de vítimas em PCR ${ }^{4}$. OBJETIVO: Descrever o desenvolvimento de um AVA como estratégia de ensino-aprendizagem no atendimento aos suportes básico e avançado de vida. METODOLOGIA: Pesquisa metodológica de desenvolvimento na modalidade de um estudo descritivo/exploratório com utilização do modelo $W I X$, um editor de sites de hospedagem gratuita e que permite explorar a criatividade para criação do AVA além de favorecer a aprendizagem colaborativa. Os objetivos educacionais do AVA foram definidos segundo os domínios cognitivo, afetivo e psicomotor da Taxonomia de Bloom, uma vez que esse ambiente proporciona aos alunos dominar um conhecimento, desenvolver habilidades, atitudes, responsabilidades e valores ${ }^{5}$. A construção do AVA ocorreu entre os meses de setembro de 2016 a fevereiro de 2017, quando se pesquisou todo conteúdo a ser abordado, a partir de exploração das bases de dados nacionais e 
internacionais, bem como em livros, protocolos e material de apoio de universidades públicas brasileiras. RESULTADOS: A página inicial do AVA dá acesso à aula, material complementar, artigos e atividades de conteúdo teórico-prático. As ações envolvidas na criação deste ambiente de aprendizagem foram cuidadosamente fundamentadas em aspectos e vivências próximos à realidade, para que resultem em conhecimentos consistentes e significativos. O AVA é de domínio público e encontra-se disponível no endereço http://joaojaconenf.wixsite.com/atendimento-a-pcr. CONCLUSÃO: Este produto tecnológico constitui uma ferramenta conclusiva para promoção da educação permanente em saúde, porém entende-se que para tal finalidade seja necessário sua submissão à avaliação qual será objeto de um estudo posterior.

\section{REFERÊNCIAS:}

1. Holanda VR, Pinheiro AKB, Holanda ER, Santos MCL. Ensino e aprendizagem em ambiente virtual: atitude de acadêmicos de enfermagem. Rev Min Enferm. 2015 jan/mar; 19(1): 141-147.

2. Horn $\mathrm{V}$. A linguagem do material didático impresso de cursos a distância. Rev FAEEBA - Educação e Contemporaneidade, Salvador, v. 23, n. 42, p. 119-130, jul./dez. 2014.

3. Frota NM, Barros LM, Araújo TM, Caldini LN, Nascimento JC, Caetano JA. Construção de uma tecnologia educacional para o ensino de enfermagem sobre punção venosa periférica. Rev Gaúcha Enferm. 2013;34(2):29-36.

4. Kawakame PMG, Miyadahira AMK. Avaliação do processo ensino-aprendizagem de estudantes da área da saúde: manobras de ressuscitação cardiopulmonar. Rev Esc Enferm USP. 2015;49(4):657-64.DOI: 10.1590/S0080-623420150000400017.

5. Ferraz APCM, Belhot RV. Taxonomia de Bloom: revisão teórica e apresentação das adequações do instrumento para definição de objetivos instrucionais. Gest. Prod., São Carlos, 2010, v. 17, n. 2, p. 421-431.

DESCRITORES: Tecnologia da Informação; Educação em Saúde; Parada

Cardiorrespiratória.

${ }^{1}$ Faculdades Integradas Padre Albino, Catanduva - São Paulo, Professor Nivel III; Faculdade de Medicina de Rio Preto - São Paulo, Mestrando do Programa Pós Graduação em Enfermagem.

²Faculdades Integradas Padre Albino, Catanduva - São Paulo, Professor Nivel I 
${ }^{3}$ Faculdade de Medicina de Rio Preto - São Paulo, Professora Doutora do Departamento de Enfermagem Especializada

CONTATO: joaojaconenf@gmail.com 